\title{
To the systematic position of Synanthedon subauratus Le Cerf, 1916 (Lepidoptera: Sesiidae)
}

\author{
К систематическому положкению Synanthedon subauratus \\ Le Cerf, 1916 (Lepidoptera: Sesiidae)
}

\author{
O.G. Gorbunov ${ }^{1}$, Yu. Arita ${ }^{2}$ \\ О.Г. Горбунов ${ }^{1}$, Ю. Арита ${ }^{2}$
}

\begin{abstract}
${ }^{1}$ A.N. Severtsov Institute of Ecology and Evolution, Russian Academy of Sciences, Leninsky prospekt 33, Moscow 119071, Russia. E-mail: gorbunov.oleg@mail.ru

${ }^{2}$ Ida 2489, Iga-shi, Mie-ken, 518-0123 Japan. E-mail: arita.yutaka@gmail.com

${ }^{1}$ Институт проблем экологии и эволюции им. А.Н. Северцова РАН, Ленинский проспект, 33, Москва 119071, Россия.
\end{abstract}

KEY WORDS: Lepidoptera, Sesiidae, Anthedonella subauratus, new combination, Indonesia, Sulawesi.

КЛЮЧЕВЫЕ СЛОВА: Lepidoptera, Sesiidae, Anthedonella subauratus, новая комбинация, Индонезия, Сулавеси.

ABSTRACT. The sesiid moth Synanthedon subauratus Le Cerf, 1916 is redescribed. A study of the genitalia of both the male and female has allowed us to establish its real systematic position within the tribe Synanthedonini and to transfer it to the genus Anthedonella O.Gorbunov, Arita, 1995, resulting in Anthedonella subaurata (Le Cerf, 1916), comb.n. The male and both the male and female genitalia of this species are described and illustrated for the first time.

How to cite this article: Gorbunov O.G., Arita Yu. 2018. To the systematic position of Synanthedon subauratus Le Cerf, 1916 (Lepidoptera: Sesiidae) // Russian Entomol. J. Vol.27. No.1. P.55-60. doi: 10.15298/ rusentj.27.1.09

РЕЗЮМЕ. Приводится переописание Synanthedon subauratus Le Cerf, 1916. Исследование гениталий как самца, так и самки позволило установить действительное систематическое положение в трибе Synanthedonini и перенести его в род Antedonella O.Gorbunov et Arita, 1999, Anthedonella subaurata (Le Cerf, 1916), comb.n. Впервые описываются и иллюстрируются самец, а также гениталии как самца, так и самки этого вида.

\section{Introduction}

The Synanthedonini is the largest sesiid tribe [Špatenka et al. 1999; Gorbunov, Gurko, 2017]. Unfortunately, in the Oriental realm this tribe is still poorly studied, even though a number of papers have appeared over the last couple decades containing descriptions of new taxa and extensive reviews of the tribe in the faunas of Vietnam and Taiwan [Arita, Gorbunov, 1995a, 1995b, 1998; Gorbunov, Arita, 1995a, 1995b, 2000, 2001a, 2001b, 2005; Gorbunov, 2015; Liang, Hsu, 2015]. According to the latest data, this tribe in the region encompasses 83 species in 12 genera [Pühringer, Kallies, 2018]. Unbelievable as it might seem, nearly half of these species (41) belong to the Palaearctic genus Synanthedon Hübner, 1819 ["1816"] (the type-species: Sphinx oestriformis Rottemburg, 1775 [=Sphinx vespiformis Linnaeus, 1761]), which we consider polyphyletic even within the Palaearctic [Gorbunov, Gurko, 2017]. Its presence in the Oriental Region is deemed simply incredible. All above suggests that the tribe Synanthedonini in the Oriental Region is in need of a serious revision. In addition, in our opinion, it is time to deal with the generic structure of the tribe within the Palearctic.

Studying the clearwing moth fauna of the island of Sulawesi, Indonesia [Gorbunov, 2016; Gorbunov, Arita, 2016], we have found a small series of an interesting Synanthedon-like species. A careful investigation of the external morphology and a comparison with different type specimens showed that all males and females of this series belong to one species, namely, Synanthedon subauratus Le Cerf, 1916, originally described also from southern Sulawesi. Further studies of both male and female genitalia allowed us to determine the actual systematic position of this species and to transfer it to the genus Anthedonella O.Gorbunov, Arita, 1999 (the typespecies: Anthedonella polyphaga O.Gorbunov et Arita, 1999), resulting in Anthedonella subaurata (Le Cerf, 1916), comb.n.

At present, we include the following nine species in this genus:

A. polyphaga O. Gorbunov et Arita, 1999 (type locality: Nepal, Koshi, Dhankuta), the type species;

A. flavida O. Gorbunov et Arita 2000 (type locality:

N. Vietnam, Ninh Binh Prov., Cuc Phuong);

A. ignicauda (Hampson, 1919) (type locality: NW Myanmar, Chindwin, Kalewa);

A. jinghongensis (Yang et Wang, 1989) (type locality: China, Yunnan, Jinghong); 
A. opalizans (Hampson, 1919) (type locality: Indonesia, North Maluku, Sula Is., Mangole Id.);

A. siberutica O. Gorbunov, 2015 (type locality: Indonesia, Mentawai Is., Siberut Id.);

A. subaurata (Le Cerf, 1916), comb.n. (type locality: Indonesia, South Sulawesi, environs of Maros);

A. subtillima (Bryk, 1947) (type locality: NE Myanmar, Kambaiti);

A. theobroma (Bradley, 1957) (type locality: Malaysia, Selangor, Seri Kembangan).

Below we take the opportunity to redescribe this species in due detail, while the male and both male and female genitalia are described here for the first time.

All images of moths were taken with a Sony $\alpha 450$ DSLR camera with a Minolta 50 Macro lens. The figures of the holotype and its labels from the Muséum national d'Histoire naturelle, Paris, France were scanned using a Nikon ${ }^{\circledR}$ LS 2000 Cool Scan from Ektachrome ${ }^{\circledR}$ slides. The genitalic images were taken with a Keyence BZ-9000 Biorevo Fluorescence Microscope. The final processing of all illustrations was performed with Adobe $^{\circledR}$ Photoshop ${ }^{\circledR}$ CS5 .

The material studied or mentioned herein is kept in the following collections: MNHP - Muséum national d'Histoire naturelle, Paris, France, COGM - the collection of the A.N. Severtsov Institute of Ecology and Evolution of the Russian Academy of Sciences, Moscow, Russia. All pictures of dry specimens are labeled with a number containing the name of the family, two consecutive digits and a year (e.g. SESIIDAE pictures №№ 0243 0244-2013). These numbers correspond to those of the figured specimens in the first author's archive.

Genital preparations are kept in microtubes pinned under the specimen. All genitals have the appropriate number placed inside the microtube. This number as a label (e.g. Genital preparation №№ OG-011-2014) is pinned under the specimen and listed in the first author's archive.

\section{Taxonomic account}

\section{Antedonella subaurata (Le Cerf, 1916), comb.n.} Figs 1-15.

"Synanthedon subauratus nov. sp." - Le Cerf 1916: 11, pl. 378, fig. 3166. Type locality: "Célèbes méridion., région basse entre Maros et Bamba, ..." [= Indonesia, South Sulawesi, environs of Maros]. Holotype $q$ (Figs 1, 2) (MNHP).

Le Cerf, 1917: 295 (Synanthedon subauratus nov. sp.); Hampson, 1919: 71 (Conopia; as a synonym of Aegeria auriplena Walker, 1865 ["1864"]); Dalla Torre, Strand, 1925: 109 (Conopia; as a synonym of Aegeria auriplena Walker, 1865 ["1864"]); Gaede, 1933: 783, pl. 94, row e (Conopia; as a synonym of Aegeria auriplena Walker, 1865 [“1864”]); Heppner, Duckworth, 1981: 29 (Synanthedon; as a synonym of Aegeria auriplena Walker, 1865 [“1864"]); Gorbunov, Arita, 1995a: 85 (Synanthedon; as a distinct species); Gorbunov, Arita, 1995b: 222 (Synanthedon; as a distinct species); Arita, Gorbunov, 1998: 152, 155 (Paranthrenella, as a distinct species); Gorbunov, Arita, 1999: (Paranthrenella, as a distinct species); Gorbunov, Arita, 2000: 96 (Paranthrenella, as a distinct species); Pühringer, Kallies, 2004: 29 (Synanthedon; as a distinct species)

MATERIAL. Holotype $q$ (Fig. 1), with labels as in Fig. 2 (MNHP); 2 O $^{7}$ (Figs 7-10), 2 우 (Figs 3-6), Indonesia: SE
Sulawesi, Tiu Lapolu, 12-18.III.2008, local collector (COGM).

DESCRIPTION. Male (Figs 7-8). Alar expanse $16.7 \mathrm{~mm}$; body length $11.5 \mathrm{~mm}$; forewing $7.9 \mathrm{~mm}$; antenna $6.1 \mathrm{~mm}$.

Head: antenna dorsally black with purple-violet sheen, ventrally light brown covered with yellow scales, with a dark brown to black apex; scapus yellow; frons brown with bright greenish-blue sheen, laterally with a narrow pale yellow stripe with golden sheen; vertex black with bright greenishviolet sheen; labial palpus yellow with individual brown scales in distal half; occipital fringe yellow dorsally and pale yellow laterally.

Thorax: patagia dark brown to black with bright greenviolet sheen; tegula dark brown to black with bright violet sheen, yellow with golden sheen both interiorly and posteriorly; mesothorax dark brown to black with violet sheen; metathorax yellow; thorax laterally brown with a large, medial, yellow spot with golden sheen; both metepimeron and metameron entirely yellow posteriorly.

Legs: neck yellow with golden sheen; fore coxa yellow with golden sheen; fore femur dark brown to black with violet sheen externally and yellow internally; fore tibia entirely yellow with golden sheen; fore tarsus dorsally yellow with golden sheen, ventrally black with greenish sheen; mid coxa dark brown with a few yellow scales; mid femur dark brown to black with bluish sheen externally and yellow internally; mid tibia yellow with golden sheen; spurs yellow with golden sheen; mid tarsus yellow with golden sheen, with admixture of dark brown scales on 2-5 tarsomeres dorsally; hind coxa dark brown with a few yellow scales; hind femur dark brown to black with bluish sheen externally and yellow internally; hind tibia yellow with golden sheen, also with a small spot dark brown to black with violet sheen at base of mid spurs externally and with a broad dark brown to black ring with violet sheen at base of apical spurs; spurs yellow with golden sheen; hind tarsus exterodorsally yellow with golden sheen with admixture of black scales with bronzed sheen at base of each tarsomere, interoventrally yellow with golden sheen.

Abdomen: dorsally black with bright violet-bronzed sheen; tergites 2, 3 and 4 each with a narrow dark yellow stripe distally; tergites 5-7 each with an orange stripe distally; tergites 4-7 each densely covered with orange scales; ventrally gradually changing from yellow to orange caudally; central part of anal tuft dorsally black with violet sheen, lateral part orange with a narrow strip black with violet sheen medially; ventrally black with bright violet-blue sheen.

Forewing: dorsally black with bronzed-blue sheen at base; costal margin, CuA-stem and anal margin dark brown to black with dark green-violet sheen, with admixture of individual yellow scales; discal spot and veins within external transparent area dark brown to black with dark violet sheen; apical area dark brown with bronzed sheen, densely mixed with orange scales between veins $R_{4}-R_{5}$ and $M_{1}-M_{2}$; ventrally yellow with golden sheen at base; costal margin, $\mathrm{R}-$ and $\mathrm{CuA}$-stems dark brown and densely covered with yellow scales; discal spots, veins $\mathrm{R}_{2}$ and $\mathrm{R}_{3}$, and veins within external transparent area dark brown to black with dark purple sheen; apical area dark brown to black with purple sheen, densely mixed with yellow scales between veins $R_{4}-R_{5}$ and $M_{1}-M_{3}$; discal spot narrow, slightly narrowed caudally, about 0.2 times as wide as external transparent area; transparent areas well-developed, covered with sparse hyaline scales with bluish-violet sheen; external transparent area large, rounded distally, divided into six cells, cell between veins $R_{4}$ and $R_{5}$ somewhat exceeding the distal margins of other cells; posterior transparent area exceeding the distal margin of discal spot; cilia dark brown with bronzed sheen. 
Hindwing: transparent; veins dark brown to black with bronzed sheen dorsally; discal spot dark brown to black with purple sheen, extremely small, cuneiform, exceeding the base of vein $\mathrm{M}_{2}$; outer margin dark brown to black with purple sheen, extremely narrow, about $1 / 3$ as broad as cilia; costal margin yellow ventrally, veins and discal spot dark brown to black with purple sheen; cilia dark brown with bronzed sheen, yellow with golden sheen anally.

Male genitalia (genital preparation OG-011-2014) (Figs 12-15). Tegumen-uncus complex narrow; scopula androco-
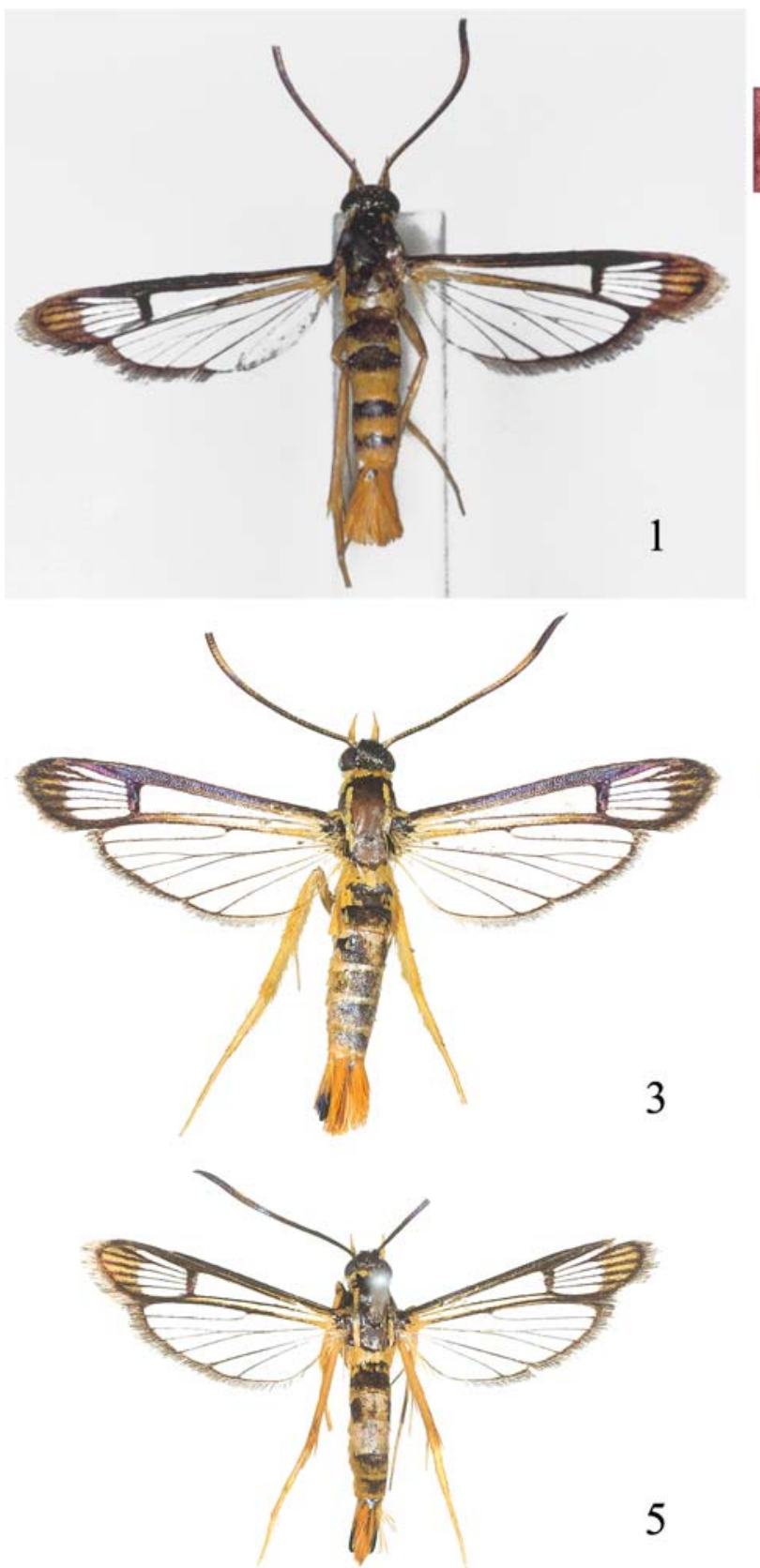

Synanthedon subauratus
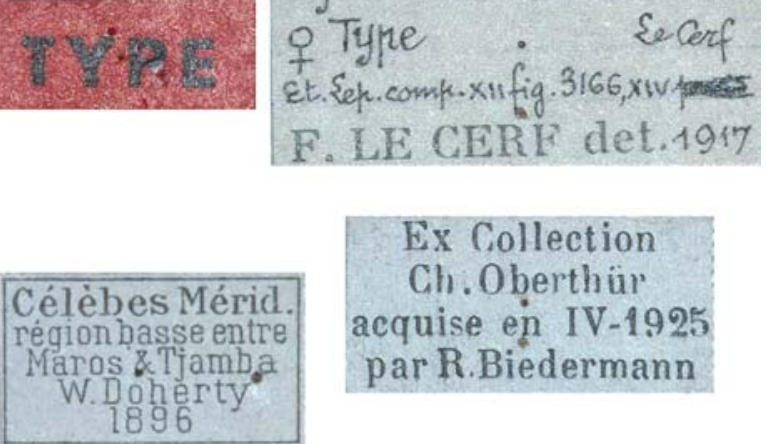

Ex Collection

Ch. Oberthür acquise en IV-1925 parR.Biedermann
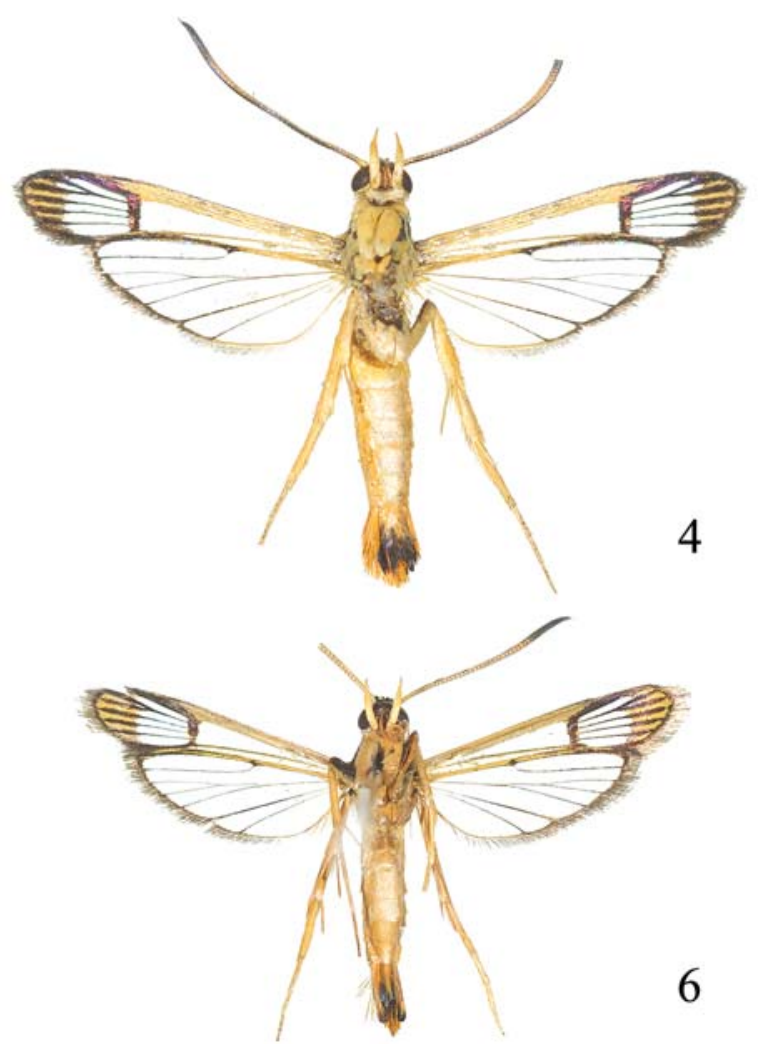

Figs 1-6. Variability of females of Antedonella subaurata, comb.n.: 1 - holotype, dorsal view. Alar expanse $19.5 \mathrm{~mm} ; 2$ - ditto, labels; 3 - dorsal view; 4 - lateral view. Alar expanse $19.0 \mathrm{~mm}$. Sesiidae pictures №№ 0243-0244-2013; 5 — dorsal view; 6 - lateral view. Alar expanse $16.0 \mathrm{~mm}$. Sesiidae pictures №№ 0249-0250-2013.

Рис. 1-6. Изменчивость самок Antedonella subaurata, comb.n.: 1 - голотип, вид сверху. Размах крыльев 19,5 мм; 2 - тоже, этикетки; 3 - сверху; 4 - снизу. Размах крыльев 19,0 мм. Снимок №№ 0243-0244-2013; 5 - сверху; 6 - снизу. Размах крыльев 16,0 mm. Снимок №№ 0249-0250-2013. 
Female (Figs 3, 4). Alar expanse $19.0 \mathrm{~mm}$; body length $11.4 \mathrm{~mm}$; forewing $9.1 \mathrm{~mm}$; antenna $6.2 \mathrm{~mm}$.

Somewhat more robust than male. Thorax entirely yellow with golden sheen laterally. Hind leg entirely yellow with golden sheen. Abdomen more densely covered with yelloworange scales dorsally, entirely yellow ventrally; central part of anal tuft yellow-orange, lateral part black with admixture of yellow scales laterally. Forewing apical area with orange scales between veins $\mathrm{R}_{4}-\mathrm{Cu}_{2}$; external transparent area large, divided into five cells, cell between veins $R_{4}$ and $R_{5}$ absent. Colour patterns otherwise as in male.

Female genitalia (genital preparation OG-012-2014) (Fig. 11). Papillae anales relatively long and narrow, covered with short setae; 8th tergite narrow and long with short setae; posterior apophysis somewhat longer than anterior apophysis; both lamellae antevaginalis and postvaginalis undeveloped; ostium bursae somewhat anterior to 8th tergite, antrum relatively narrow, slightly broadened at ostium, long, about half as long as anterior apophysis, well-sclerotized; ductus seminalis stemming just from anterior margin of antrum; ductus bursae well-sclerotized at ductus seminalis, then membranous, narrow, slightly broadened towards corpus bursae; relatively long, about twice as long as antrum; corpus bursae globose to ovoid, without signum, but with numerous flat spinules.

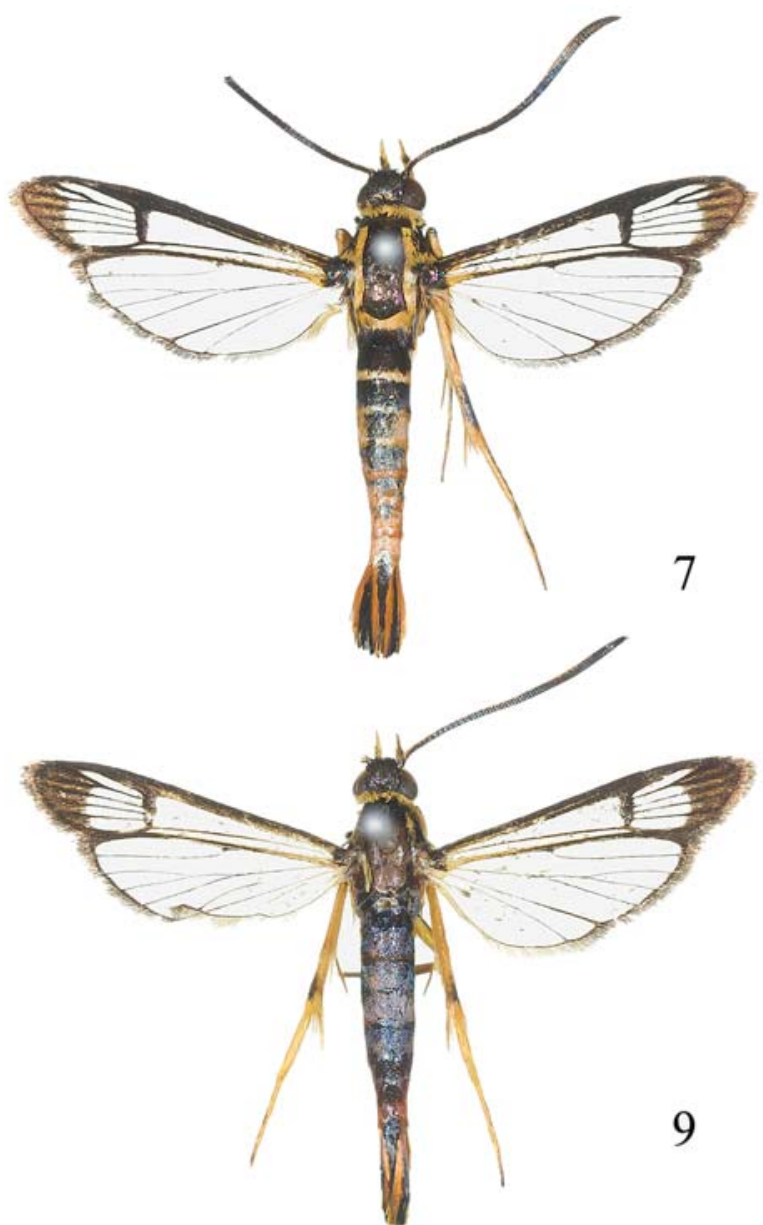

INDIVIDUAL VARIABILITY. This species slightly varies in the number of yellow scales on the thorax, abdomen and forewing. Besides this, the size and number of cells in the external transparent area of the forewing are inconstant (see Figs 1,2-10). Both males and females are somewhat variable in individual size. Males: alar expanse $16.7-16.2 \mathrm{~mm}$; body length $11.5-11.0 \mathrm{~mm}$; forewing 7.9-7.6 $\mathrm{mm}$; antenna $6.1-$ $5.8 \mathrm{~mm}$. Females: alar expanse $19.5-16.0 \mathrm{~mm}$; body length 11.6-9.0 mm; forewing $9.3-7.3 \mathrm{~mm}$; antenna $6.2-5.2 \mathrm{~mm}$.

DIFFERENTIAL DIAGNOSIS. Superficially, $A$. subaurata (Le Cerf, 1916), comb.n. seems to be the closest to $A$. opalizans, but it can be distinguished by the conformation of the external transparent area of the forewing (more narrow with a straight and oblique distal margin, level to vein $\mathrm{M}_{2}$ about as broad as apical area in the species compared) and by the absence of yellow scales between veins in the apical area of the forewing. From A. flavida this species is easily separable by the coloration of the abdomen dorsally [male tergites 2 , 4 and 6 each with a narrow yellow-orange stripe distally, female tergite 2 with a narrow, tergite 4 with a broad and tergites 5 and 6 each with an extremely narrow yellow-orange stripe distally in A. flavida [compare Figs 1, 3, 5, 7 and 9 with figs 9 and 10 in Gorbunov, Arita, 2000], by the coloration of the anal tuft (dorsally dark brown to black with bronze-purple

Figs 7-10. Variability of males of Antedonella subaurata, comb.n.: 7 - dorsal view; 8 - lateral view. Alar expanse 16.7 mm. Sesiidae pictures №№ 0245-0246-2013; 9 - dorsal view; 10 - lateral view. Alar expanse 16.2 mm. Sesiidae pictures №№ 0247-0248-2013.

Рис. 7-10. Изменчивость самцов Antedonella subaurata, comb.n.: 7 - сверху; 8 - снизу. Размах крыльев 16,7 мм. Снимок №o 0245-0246-2013; 9 - сверху; 10 - снизу. Размах крыльев 16,2 mm. Снимок №№ 0247-0248-2013. 
sheen, with two elongated yellow spots medially and with an admixture of yellow scales laterally in the male and dark brown to black with green-bronze sheen, mixed with dark yellow to yellow-orange scales in the female of the species compared), by the conformation of the crista gnathi, crista sacculi and saccus in the male genitalia [compare Figs 12-14 with figs 20a-c Gorbunov, Arita, 2000] and by the shapes of the antrum, ductus bursae and corpus bursae in the female genitalia [see Fig. 11 and fig. 27 in Gorbunov, Arita, 2000]. From $A$. siberutica this species differs by the coloration of the antenna (dorsally with a yellow spot in the apical quarter in the species compared), abdomen dorsally (each tergite with a narrow stripe yellow with golden sheen distally, the stripe on tergite 4 broadened laterally in A. siberutica), by the structure of the external transparent area of the forewing (trapeziform, level to vein $\mathrm{M}_{2}$ ca 4.2 times (male) or about twice (female) broader than discal spot; distal margin of cell between veins $\mathrm{R}_{3}$ and $\mathrm{R}_{4}$ slightly exceeding the distal margins of cells between veins $\mathrm{R}_{4+5}-\mathrm{CuA}_{1}$ in A. siberutica) and by the conformation of both male and female genitalia [compare Figs 11-15 with figs 5-8 in Gorbunov, 2015]. From other congeners, such as A. ignicauda, A. jinghongen-

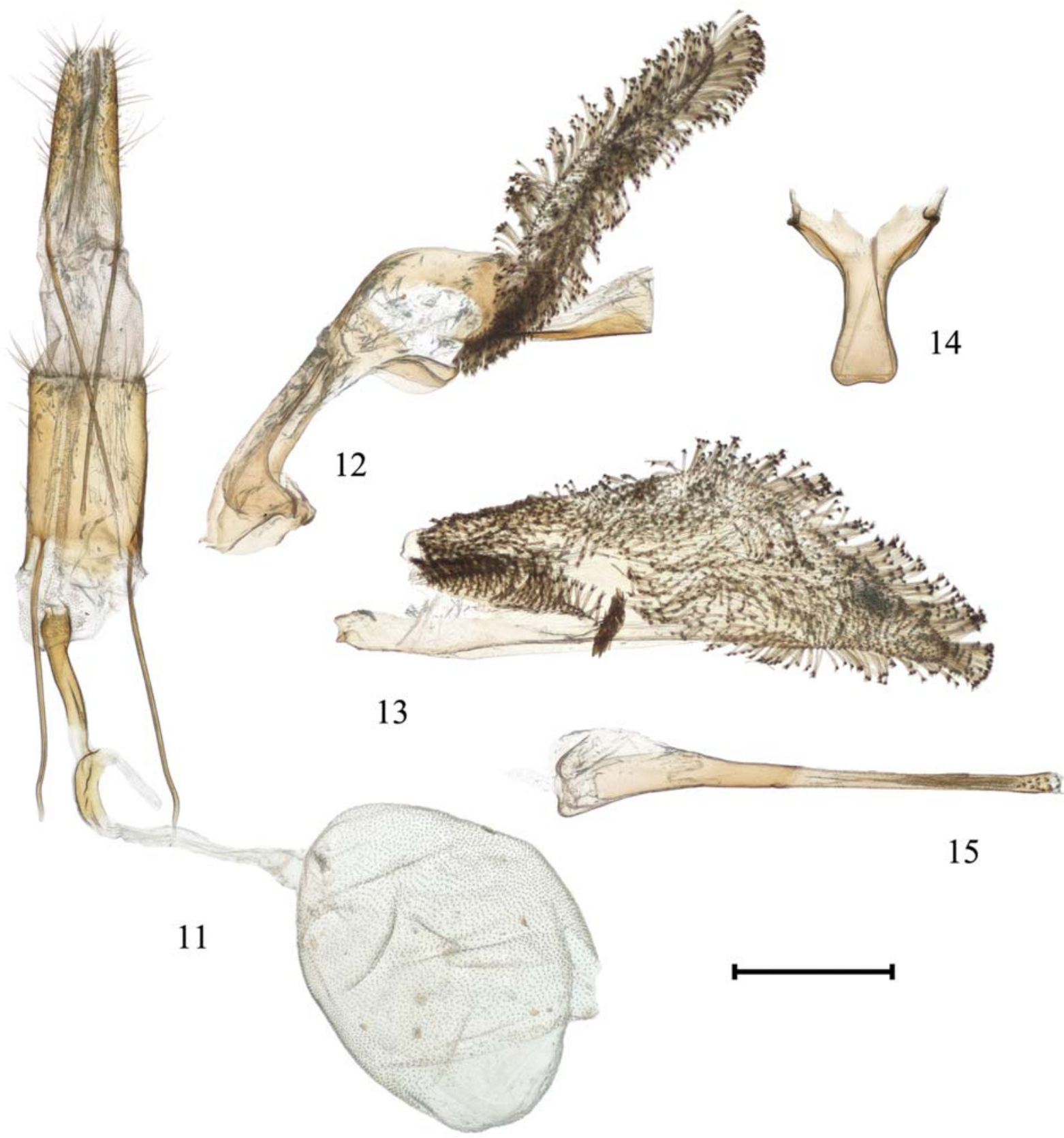

Figs 11-15. Genitalia of Antedonella subaurata, comb.n.: 11 - female. Genital preparation № OG-012-2014. 12-15 male. Genital preparation № OG-012-2014; 12 - tegumen-uncus complex; 13 - valva; 14 - saccus; 15 - aedeagus. Scale bar $0.25 \mathrm{~mm}$ for 11 and 0.5 for $12-15$.

Рис. 11-15. Гениталии Antedonella subaurata, comb.n.: 11 - самка. Препарат гениталий № OG-012-2014. 12-15 самец. Препарат гениталий № OG-012-2014; 12 — тегумен-ункус комплекс; 13 — вальва; 14 - саккус; 15 — эдеагус. Масштаб 0,25 мм для 11 и 0,5 мм для $12-15$. 
sis, A. polyphaga and A. subtillima, A. subaurata clearly differs by the coloration of the anal tuft (with bright redorange, brick-red or fiery-red scales medially in all these species compared).

BIONOMICS. The host plant and larval bionomics are unknown. The specimens of the studt material were collected in mid-March.

HABITAT. Unknown.

DISTRIBUTION. At present, this species is known to occur at two localities in the south of Sulavesi, Indonesia.

ACKNOWLEDGEMENTS. We express our sincere gratitude to Dr Joel Minet (Paris, France), curator of the collection of Lepidoptera at the Muséum national d'Histoire naturelle, Paris, France (MNHP), for the opportunity to work with the collection under his care. We also thank two anonymous reviewers and Dr S.I. Golovatch (Moscow, Russia) who kindly checked the English of advanced drafts.

The study was conducted using the equipment of the Joint Usage Center "Instrumental methods in ecology" at the A.N. Severtsov Institute of Ecology and Evolution, Russian Academy of Sciences, Moscow, Russia.

\section{References}

Arita Y., Gorbunov O.G. 1995a. A review of the genus Macrotarsipus Hampson, [1893] (Lepidoptera, Sesiidae) of the Oriental region // Trans. Lepid. Soc. Japan. Vol.46. No.2. P.103-111.

Arita Y., Gorbunov O.G. 1995b. Sesiidae of Nepal // Haruta T. (ed.). Moths of Nepal. Part 4. Tinea. Vol.14. Suppl.2. P.194-206. P1.108, 128.

Arita Y., Gorbunov O.G. 1998. A revision of Embrik Strand's clearwing moth types (Lepidoptera: Sesiidae) from Taiwan // Chinese J. Entomol. Vol.18. P.141-165.

Dalla Torre K.W. von, Strand E. 1925. Aegeriidae // Strand E. (Hrsg.) Lepidopterous Catalogus. Bd. 31. Berlin: W. Junk. 202 pp.

Gaede M., 1933. 23 Familie: Aegeriidae // Seitz A. (Hrsg.). Die Gross-Schmetterlinge der Erde. Bd.10. Stuttgart: A Kernen Verlag. S.775-802. Tab.94-95.

Gorbunov O.G. 2015. A new species of the genus Anthedonella O. Gorbunov et Arita, 1999 from the island of Siberut, Mentawai, Indonesia // Far Eastern Entomologist. No.299. P.11-17.

Gorbunov O.G. 2016. Nokona mahawu sp. n., a new clearwing moth species (Lepidoptera, Sesiidae) from North Sulawesi, Indonesia // Russian Entomol. J. Vol.25. No.2. P.161-165.

Gorbunov O.G., Arita Y. 1995a. New and poorly known clearwing moth taxa from Vietnam (Lepidoptera, Sesiidae) // Trans. Lepid. Soc. Japan. Vol.46. No.2. P.69-90.
Gorbunov O.G., Arita Y. 1995b. A revision of Frederic Moore's clearwing moth types (Lepidoptera, Sesiidae), at Humboldt University, Berlin // Tinea. Vol.14. No.3. P.204-224.

Gorbunov O.G., Arita Y. 1999. New taxa of the clearwing moths (Lepidoptera, Sesiidae) from Nepal // Tinea. Vol.16. No.2. P.106-143.

Gorbunov O.G., Arita Y. 2000. Study on the Synanthedonini (Lepidoptera, Sesiinae) of Vietnam // Japanese J. Systematic Entomol. Vol.6. No.1. P.85-113.

Gorbunov O.G., Arita Y. 2001a. A new species of the genus Ravitria Gorbunov \& Arita (Lepidoptera, Sesiidae) from Yunnan, China // Trans. Lepid. Soc. Japan. Vol.52. No.4. P.245-249.

Gorbunov O.G., Arita Y. 2001b. A revision of Felix Bryk's clearwing moth types (Lepidoptera, Sesiidae), at the Naturhistoriska Riksmuseet in Stockholm, Sweden. // O.G. Gorbunov (Ed.), Melittia, a Lepidopterological Almanac. Vol.1. P.9-51.

Gorbunov O.G., Arita Y. 2005. A new genus and two new species of Synanthedonini (Lepidoptera, Sesiidae) from the Oriental Region // Tinea. Vol.18. Suppl.3. P.86-95.

Gorbunov O.G., Arita Y. 2016. A new species of the genus Cyanosesia O. Gorbunov et Arita from South-East Sulawesi, Indonesia (Lepidoptera: Sesiidae) // Euroasian Entomol. J. Vol.15. Suppl.1. P.35-39.

Gorbunov O.G., Gurko V.O. 2017. A new genus and species of clearwing moths (Lepidoptera: Sesiidae) from South Sudan // Zootaxa. Vol.4276. No.2. P.270-276.

Hampson G.F 1919. A classification of the Aegeriadae [sic!] of the Oriental and Ethiopian regions // Novitates Zoologicae. Vol.26. P.46-119.

Heppner J.B., Duckworth W.D. 1981. Classification of the Superfamily Sesioidea (Lepidoptera: Ditrysia) // Smithson. Contr. Zool. Vol.314. P.iii +144 .

Le Cerf F. 1916. Explication des planches // Étud. Lépid. comp. Vol.12. No.1. P.7-14. Pl.373-381.

Le Cerf F. 1917. Contributions à l'étude des Aegeriidae: Description et iconographie d'espèces et de formes nouvelles ou peu connues // Étud. Lépid. comp. Vol.14. P.137-388.

Liang J.-Yu., Hsu Yu-F. 2015. A review of clearwing moths in the tribe Synanthedonini, with description of six new species from Taiwan (Lepidoptera: Sesiidae) // Zootaxa. Vol.4044. No.4. P.535-555.

Pühringer F., Kallies A. 2004. Provisional checklist of the Sesiidae of the world (Lepidoptera: Ditrysia) // Mitt. Ent. Arb.gem. Salzkammergut. Bd.4. S.1-85.

Pühringer F., Kallies A. 2018. Checklist of the Sesiidae of the world (Lepidoptera: Ditrysia). http://www.sesiidae.net/ Checklst.htm (accessed 23 January 2018)

Špatenka K., Gorbunov O., Laštùvka Z., Toševski I., Arita Y. 1999. Sesiidae, Clearwing Moths // Naumann C.M. (Ed.). Handbook of Palaearctic Macrolepidoptera. Vol.1. Gem Publishing Company, Wallingford. 569 pp. 